\title{
ОСОБЛИВОСТІ ПСИХОЛОГІЧНОГО БЛАГОПОЛУЧЧЯ СТУДЕНТІВ РІЗНИХ ПРОФІЛІВ ПІДГОТОВКИ
}

\begin{abstract}
Анотація. У статті викладені результати емпіричного дослідження, що висвітлюють психологічні особливості благополуччя студентів різних профрілів підготовки. Встановлено, що психологічне благополуччя студентів обумовлене обраним ними фахом. Так, студенти-психологи, приділяючи достатньо уваги своєму особистісному розвитку та надаючи вагомої ролі системі комунікацій у професійному становленні, характеризуються більш вираженими показниками психологічного благополуччя, соціального та емоційного здоров'я, що реалізується за рахунок активного включення у відносини, надання й отримання підтримки, дотримання автономії, зростання і досягнень особистості. Натомість студенти технічних спеціальностей, не надаючи особистісному розвитку вагомого значення під час професіоналізації, характеризуються нижчими показниками психологічного благополуччя, хоча більше цілеспрямовані у житті, схильні реалізуватися у виробничій діяльності, не маючи вираженої залежності якості життя від успішності в системі комунікацій.
\end{abstract}

Ключові слова: психологічне благополуччя, особистість студента, якість життя, фізичне здоров’я, емоційне здоров'я, соціальне здоров’я.

Kharchenko Anzhela

Poltava National V.G. Korolenko Pedagogical University

\section{PECULIARITIES OF PSYCHOLOGICAL WELL-BEING OF STUDENTS OF DIFFERENT TRAINING PROFILES}

Summary. The article presents the results of an empirical study concerning the peculiarities of the psychological well-being of students of different specialties. It is established that psychology students are characterized with more pronounced rates of the integrated indicator of well-being, autonomy, environmental management, personal growth and self-perception. Paying constant attention to their personal growth in the process of professional training, psychology students evaluate their own personality mostly positively, treat themselves as people who have realized their potential, able to participate in the system of relations with people actively and to maintain the autonomy in such relationships. Students of technical specialties are characterized with slightly reduced indicators of psychological well-being, personal growth and self-perception, autonomy, environmental management, with a significant advantage of life goals manifestation. Such students have some worrying due to their own unproductiveness, inability to be fulfilled in life. At the same time, having a strong dependence on the social environment, such students are mostly incapable of autonomy, although they have clearly defined life goals and focus their activities on achieving them. Psychology students are characterized with higher indicators of quality of life, are characterized with more raised personal achievements and have deeper relationships with relatives, greater psychological support in life and self-control. Instead, students of technical specialties have lower indicators of quality of life, not having such an extensive system of personal achievements, inclusion into interpersonal interaction, manifestations of care and concern for others. Psychology students are characterized with more pronounced indicators of emotional well-being and social health. Comparing with students of technical specialties they are mostly able to experience positive emotional states, are less strained in life and more effective in the communication system, where they can resolve conflicts successfully and be flexible with others. This, in general, corresponds to their chosen specialty of professional development and testifies to the success of the formation of professionally important qualities of a psychologist among these respondents. Instead, students of technical specialties experience the raised emotional tension and a tendency to open confrontation with others, which is due to the lack of purposeful development of personal characteristics of the subjects during professional training. It was also found that students, regardless of the chosen profession, give a significant role to the relationships in life and a high level of physical health.

Keywords: psychological well-being, student personality, quality of life, physical health, emotional health, social health.

$\Pi^{2}$ остановка проблеми. Сучасна економічна та соціальна ситуація розвитку суспільства суттево впливає на якість життя особистості, їі психологічне благополуччя.

Студентський вік є періодом найбільшої активності, професійного становлення, а також формування ціннісних утворень особистості. Соціальна ситуація розвитку у цей період пов'язана з вибором життевого шляху, професійним та особистісним самовизначенням.

Психологи наголошують, що навчання у закладі вищої освіти е принципово новим етапом життям особистості. Причому відмічається як збільшення інформаційних навантажень, так i ускладнення міжособистісних відносин, що може призводити до тривалого емощійного напруження, почуття тривоги, а також переживання психологічного неблагополуччя.

Особливо зростає необхідність вивчення психологічного благополуччя під час пандемії коронавірусу COVID-19 (О. І. Рассказова, Д. О. Леонтьев, Г. О. Лебедева [4], І. Г. Тітов, Т. С. Тітова, К. В. Седих, S. Giacomuzzi, M. Ertl, M. Rabe [6] та інші).

Аналіз останніх досліджень і публікацій. Проблемі психологічного благополуччя сучасних студентів присвячені праці психологів Т. О. Боро- 
довіциної, І. М. Габа, Н. В. Гранкіної-Сазонової, Н. О. Гончарової, Л. Б. Козьміної, Т. М. Маланьїної, М. М. Павлюк, Л. З. Сердюк, Т. Л. Ткачук, А. С. Харченко, О. Л. Шопша та інших психологів.

Л. З. Сердюк [5] схарактеризувала особистісний потенціал психологічного благополуччя студентів. Нею встановлено, що психологічне благополуччя особистості пов'язане 3 ціннісно-смисловими орієнтаціями (життевими цілями, процесом життя, результативністю життя) та життестійкістю особистості. Відтак психологічне благополуччя особистості можна вважати психологічною основою безпеки особистості, що виконуе саморегулятивну фрнкцію збереження цілісності і стабільності особистості як психологічної системи. Особистісний потенціал психологічного благополуччя полягає в реалізаціі внутрішніх ресурсів, накопичених особистістю в результаті осмислення зв'язку свого минулого, теперішнього і майбутнього з точки зору реалізації своїх можливостей і досягнення життевих перспектив - резервів повноцінної реалізаціі в теперішньому та можливості розвитку свої життевих сил, трудових і духовних здібностей у майбутньому.

У нашому дослідженні, проведеному спільно з Н. О. Гончаровою, проаналізовано особливості психологічного благополуччя студентів із різним типом спрямованості. Так, психологічне благополуччя студентів із гуманістичною спрямованістю характеризуються позитивними відносинами з оточуючими, управлінням середовищем, задоволеністю життям та його умовами; студентів із прагматичною спрямованістю - високим рівнем цілей у житті, автономіею та задоволенням основних життевих потреб; студентів із екзистенційною спрямованістю - особистісним зростанням та самоприйняттям; студентів із егоцентричною спрямованістю - високим рівнем психосоціального стресу і нижчими значеннями показників психологічного благополуччя порівняно з іншими групами досліджуваних. За показником психологічного благополуччя “самооцінка здоров'я» відмінностей між групами студентів 3 різною спрямованістю виявлено не було [7].

М. М. Павлюк, О. Л. Шопша, Т. Л. Ткачук [3] у своєму дослідженні показали, що у студентів серед чинників психологічного благополуччя лише «автономія» мае виразну вікову динаміку. При переході від третього до п'ятого курсу значимо зменшуються ï̈ показники. Кількість студентів із низьким рівнем прояву «автономії» збільшуеться із курсом навчання, кількість тих, хто мае середні показники - коливається, а кількість високоавтономних - статистично значимо не змінюеться. Серед факторів психологічного благополуччя найвищі показники мають фактори «особистісне зростання» і «цілі у житті», а найнижчі - «управління середовищем» $\mathrm{i}$ «автономія».

На підставі проведеного дослідження Н. В. Гранкіна-Сазонова [2] дійшла висновку про те, що професію психолога не обирають особистості з низьким рівнем психологічного благополуччя в надії знайти засоби його підвищити. Навпаки, студенти-психологи демонструють вищі рівні позитивного фрункціонування особистості. Скоріше професію психолога обирають особистості з високою мотивацією особистісного росту, високим самоприйняттям (яке $є$ основою для високого рівня прийняття інших людей, що необхідно для ефективної професійної діяльності особистості), позитивними ставленням до з інших людей та такі, що мають цілі в житті; це й сприяе усвідомленому вибору професії. Проте Т. О. Бородовіцина [1], навпаки, виявила низький рівень психологічного благополуччя у студентів-психологів першого курсу, що відбивається в їх критичному самосприйнятті та нестійкій самооцінці.

Виділення не вирішених раніше частин загальної проблеми. У сучасній психологічній науці бракуе досліджень, в яких виявлялися б особливості психологічного благополуччя студентів, що навчаються за різними профілями. Такі дослідження мають поодинокий характер, проте, 3 метою оптимізації психологічного благополуччя потребуе поглибленого вивчення його специфіка у студентів різних профілів підготовки.

Мета статті. Головна мета цієї роботи полягає в аналізі результатів емпіричного дослідження особливостей психологічного благополуччя студентів спеціальності «Психологія» і технічних спеціальностей.

Виклад основного матеріалу. Дослідження проводилося на базі Полтавського національного педагогічного університету імені В. Г. Короленка та Національного університету «Полтавська політехніка імені Юрія Кондратюка» У дослідженні взяли участь 60 студентів: 36 із них навчаються за спеціальністю «Психологія» 24 опановують технічні спеціальності.

В емпіричному дослідженні використані такі методики: «Шкала психологічного благополуччя» (К. Д. Ріфф, адаптація Т. Д. Шевеленкової і П. П. Фесенка); методика оцінки рівня задоволеності якістю життя (за Н. С. Водоп'яновою) та методика самооцінки фрізичного, психічного (емоційного) і соціального здоров'я (за С. С. Степановим).

У результаті дослідження структури психологічного благополуччя встановлено, що студентипсихологи, на відміну від студентів технічних спеціальностей, характеризуються більш вираженим інтегральним показником благополуччя. Так, у більшої кількості досліджуваних студентів-психологів $(62 \%)$ виявлено високий рівень психологічного благополуччя. У студентів технічних спеціальностей його мала половина досліджуваних (50\%). Приблизно однакова кількість (студентівпсихологів - $26 \%$, студентів технічних спеціальностей $-28 \%$ ) продемонструвала середній рівень психологічного благополуччя. Більша кількість студентів технічних спеціальностей $(22 \%)$, на відміну від студентів-психологів (12\%), мала низький рівень психологічного благополуччя.

Студенти-психологи, порівняно із студентами технічних спеціальностей, характеризуються більш вираженими показниками автономії (відповідно $52 \%$ та $25 \%$ ), управління середовищем (відповідно 36\% та 17\%), особистісного зростання (відповідно $38 \%$ та $12 \%$ ), самосприйняття (відповідно $38 \%$ та 23\%). Натомість досліджувані технічних спеціальностей характеризуються перевагою у постановці цілей у житті, адже 57\% представників групи мають високий рівень даної якості порівняно з 19\% студентів-психологів. 
Тобто, студенти-психологи в силу обраного ними dpaxy та спеціально організованої навчальнопрофесійної діяльності, спрямованої на саморозвиток та оптимізацію особистісного потенціалу 3 метою надання допомоги клієнтам, мають позитивне сприйняття самих себе, більше усвідомлюють свої особистісні характеристики, що не відмежовуються від їх ідеалізованого бачення особистості загалом. Вони почувають себе здебільшого благополучно i позитивно оцінюють свої особистісні якості, характеристики та можливості у професійному зростанні.

Високий рівень психологічного благополуччя, властивий студентам-психологам, реалізуеться через різні аспекти даного феномену. Зокрема, при враженій спрямованості на встановлення близьких контактів з оточуючими, яка характерна всім студентам, майбутні психологи спроможні й до автономії, що виявляеться в їх можливості перебувати на самоті, самодостатності, спрямованості на «внутрішню впорядкованість» життя.

Властивий студентам-психологам внутрішній комфорт і можливість перебувати як у відносинах, так і на самоті, виявляеться у їх балансі внутрішнього-зовнішнього у житті, спроможності організовувати соціальну взаємодію та керувати соціальним середовищем. Вони здатні таким чином організувати соціальну взаемодію, щоб саме у ній задовольняти власні особистісні потреби, а діяльність інших людей вони заохочують у тих copepax, які важливі для них самих. Така спроможність організовувати соціальну взаємодію дає студентам виражене почуття благополуччя та комфорту, вони добре почувають себе в соціальному оточенні. При цьому виражений показник особистісного зростання у студентів-психологів виявляеться в тому, що вони вважають себе такими, що реалізувалися у житті і розвинули власний особистісний потенціал. Вони задоволені власними особистісними характеристиками, вважають себе розвинутими і прагнуть подальшого розвитку.

Також студентам-психологам властиві підвищені показники самосприйняття. Тобто досліджувані - майбутні психологи - переважно позитивно сприймають самих себе, власну особистість розцінюють як цікаву та неординарну, проте, мають більш ідеалізовані уявлення про власне «Я», відчувають розбіжність між реальним «Я» та ідеальним. Натомість студенти технічних спеціальностей мають деякі переживання через власну непродуктивність, неспроможність реалізуватися у житті. Для них характерні негативні переживання $з$ приводу власної особистості, зниженого потенціалу. При цьму, маючи виражену залежність від соціального оточення, такі студенти переважно не спроможні до автономіі. Перебування на самоті для студентів, які навчаються за технічними спеціальностями, нестерпне. Для них не характерна самототожність, спроможність не залежати від оточуючих; вони постійно потребують зовнішньої стимуляції своєї поведінки і діяльності, підвищення самооцінки за рахунок позитивної оцінки від оточуючих людей. Сощіальне оточення у таких студентів має домінувальний характер i висуває до них вимоги поведінки і діяльності, що можуть їм суттево не подобатися. Але такі студенти піддаються впливам соціального оточення, хоча й не вважають прийняті у соціальному оточенні тенденщії правильними.

Разом із цим студенти, які навчаються за технічними спеціальностями, характеризуються чітко визначеними цілями у житті та характерною їм спрямованістю на досягнення бажаного результату. Вони чітко усвідомлюють свої життеві цілі та едективно організовують свою діяльність по їх досягненню. Тобто досліджувані сприймають своє життя як підкорене чіткій і конкретній цілі, а його плинність - як проходження послідовних етапів по її досягненню.

Також встановлено, що всі досліджувані характеризуються здебільшого позитивними відносинами з оточуючими, що виступає загальною тенденцією юнацького віку та відбиває спрямованість на сощіальну взаємодію. Для всіх досліджуваних, не залежно від профрілю підготовки, властива спроможність до встановлення відкритих і психологічно близьких контактів із оточуючими людьми, спрямованість як на пізнання оточуючих і спілкування, так і на прояв власних особистісних характеристик у відносинах 3 іншими людьми. Головна їх риса в міжособистісній взаємодії - спроможність відкриватися у відносинах та довіряти іншій людині.

Студенти-психологи, порівняно зі студентами технічних спеціальностей, характеризуються більш високими показниками якості життя (відповідно 58\% та 46\%), характеризуються більш вираженими особистими досягненнями (відповідно 55\% та 28\%), мають більш виражені глибокі стосунки 3 близькими людьми (відповідно 47\% та $22 \%$ ), мають більшу підтримку у житті (відповідно 55\% та 26\%) та вищий самоконтроль (відповідно 57\% та 16\%). Тобто досліджувані-психологи характеризуються білыш вираженою якістю життя, розцінюють себе як носіїв значимих особистих досягнень, спроможних до самореалізації, розкриття власного особистісного потенщіалу та можливостей. Вони надають значення близьким міжособистісним стосункам, що, загалом, відповідає специфріці профресіоналізащії особистості психолога, її соціальній спрямованості та вагомості системи відносин для фрахівців цього профілю.

Проте за показником "робота" студенти технічних спеціальностей мають вищий рівень, ніж студенти-психологи (відповідно $50 \%$ та 27\%). Тобто основною характеристикою, що забезпечуе якість життя для студентів технічних спещіальностей, є реалізація у роботі й професійній діяльності. Вони відчувають себе задоволеними й успішними не стільки в системі якісних міжособистісних відносин, скільки реалізуючись у трудовій діяльності. Таке їх ставлення до якості життя, загалом, відповідає обраному ними фраху, де вагома роль належить саме трудовій діяльності, що менше передбачає розгалуженої системи спілкування і контактів, ніж у психологів.

За показниками здоров'я, оптимістичності, напруженості та негативних емощій значних відмінностей між групами студентів виявлено не було.

Визначено, що студенти різних профрілів навчання суттево не відрізняються за рівнем фізичного здоров'я. Так, високий його рівень властивий $82 \%$ студентів технічних спеціальностей і 75\% студентів-психологів. Тобто фрізичне здоров'я виражене на достатньо високому рівні 
у цієї групи представників юнацького віку, що пов'язано 3 відсутністю хронічних захворювань, недомагання та загострення захворювань. Середній рівень фрізичного здоров'я притаманний $15 \%$ студентам-психологам і $10 \%$ студентам технічних спещіальностей. Низький рівень виявлено у 10\% майбутніх психологів і $8 \%$ студентів технічних спеціальностей.

Високий рівень емоційного здоров'я властивий більшій кількості (35\%) студентів-психологів, ніж студентів технічних спеціальностей (10\%). Середній рівень - 20\% - студентам-психологам і $15 \%$ студентам технічних спеціальностей. Низький рівень емощійного здоров'я притаманний більшій кількості студентів технічних спеціальностей (75\%), ніж студентів-психологів (45\%).

$33 \%$ студентів-психологів мали високий рівень соціального здоров'я, тоді як такий рівень було виявлено лише у 5\% студентів технічних спеціальностей. Середній рівень сощіального здоров'я притаманний більше студентам-психологам (15\%), ніж студентам технічних спеціальностей (25\%). Низький рівень соціального здоров'я виявила більша кількість студентів технічних спещіальностей (80\%), ніж студентів-психологів (42\%).
Висновки і пропозиції. Отже, психологічне благополуччя студентів обумовлене обраним ними фрахом, що передбачає різні формми навчально-профресійної активності та відмінний ступінь особистісного саморозвитку. Так, студенти-психологи, приділяючи увагу власному особистісному розвитку та надаючи вагомої ролі системі комунікацій у професійному становленні, характеризуються більш вираженими показниками психологічного благополуччя, соціального та емоційного здоров'я, що реалізується за рахунок активного включення у відносини, надання й отримання підтримки, дотримання автономії, зростання і досягнень особистості. Натомість студенти технічних спеціальностей, не надаючи особистісному розвитку вагомого значення під час професіоналізації, характеризуються нижчими показниками психологічного благополуччя, хоча більше цілеспрямовані у житті, схильні реалізуватися у виробничій діяльності, не маючи вираженої залежності якості життя від успішності в системі комунікацій.

Перспективою нашого дослідження є розробка програми оптимізації психологічного благополуччя студентів різних профілів підготовки.

\section{Список літератури:}

1. Бородовицына Т. О. Особенности психологического благополучия студентов различных продилей подготовки. Мир науки. Педагогика и психология. 2020. № 4. URL: https://mir-nauki.com/PDF/45PSMN420.pdf

2. Гранкіна-Сазонова Н. В. Психологічне благополуччя та життестійкість студентів-психологів як важливі чинники освоєння продесіiі. Psychological journal. 2018. № 7. С. 23-42.

3. Павлюк М., Шопша О., Ткачук Т. Психологічне благополуччя як передумова розвитку особистісної самостійності майбутнього. Наука і освіта. 2018. № 1. С. 149-156.

4. Рассказова Е. И., Леонтьев Д. А., Лебедева А. А. Пандемия как вызов субъективному благополучию: тревога и совладание. Вызовы панделии COVID-19: психическое здоровье, дистаниионное образование, интернетбезопасность : сб. материалов. Т. 1. / за ред. В. В. Рубцова, А. А. Марголиса, И. В. Вачкова, О. В. Вихристюк, Н. В. Дворянчикова, Т. В. Ермоловой, Ю. М. Забродина, Н. Н. Толстых, А. В. Хаустова, А. Б. Холмогоровой, А. А. Шведовской. Москва : Издательство ФГБОУ ВО МГППУ, 2020. С. 142-160.

5. Сердюк Л. З. Структура та функція психологічного благополуччя особистості. Актуальні проблели психологї. Збірник наукових праць Інституту психологї̈ імені Г.С. Костюка НАПН України. Тол V: Психофбізіологія. Психологія праці. Експериментальна психологія. Вип. 17. Київ, 2017. С. 124-133.

6. Тітов I. Г., Тітова Т. Є., Седих К. В., Giacomuzzi S., Ertl M., Rabe М. Психологічне благополуччя особистості в період пандемії COVID-19. Психологія і особистість. 2020. Вип. 2(18). С. 55-76.

7. Харченко А. С., Гончарова Н. О. Особливості психологічного благополуччя студентів із різним типом спрямованості. Психологія і особистість. 2017. № 2(12). С. 185-193.

\section{References:}

1. Borodovicyna, T. O. (2020). Osobennosti psihologicheskogo blagopoluchija studentov razlichnyh profilej pidgotovki [Features of psychological well-being of students of various profiles of preparation]. Mir nauki. Pedagogika $i$ psihologija [The world of science. Pedagogy and psychology], 4. Retrieved from: https://mir-nauki.com/ PDF/45PSMN420.pdf (in Russian)

2. Hrankina-Sazonova, N. V. (2018). Psykholohichne blahopoluchchia ta zhyttiestiikist studentiv-psykholohiv yak vazhlyvi chynnyky osvoiennia profesii [Psychological well-being and vitality of students-psychologists as important factors of mastering the profession]. Psychological journal [Psychological journal], 7, 23-42. (in Ukrainian)

3. Pavliuk, M., Shopsha, O., \& Tkachuk, T. (2018). Psykholohichne blahopoluchchia yak peredumova rozvytku osobystisnoi samostiinosti maibutnoho [Psychological well-being as a prerequisite for the development of personal independence of the future]. Nauka i osvita [Science and education], 1, 149-156. (in Ukrainian)

4. Rasskazova, E. I., Leont'ev, D. A., \& Lebedeva, A. A. (2020) Pandemija kak vyzov sub\#ektivnomu blagopoluchiju: trevoga i sovladanie. Vyzovy pandemii COVID-19: psihicheskoe zdorov'e, distancionnoe obrazovanie, internetbezopasnost': sb. materialov, t. 1. Moskva: Izdatel'stvo FGBOU VO MGPPU.

5. Serdiuk L. Z. (2017). Struktura ta funktsiia psykholohichnoho blahopoluchchia osobystosti. Aktualni problemy psykholohii. Zbirnyk naukovykh prats Instytutu psykholohii imeni H.S. Kostiuka NAPN Ukrainy. Tom V: Psykhofiziolohiia. Psykholohiia pratsi. Eksperymentalna psykholohiia, pp. 124-133. Kyiv.

6. Titov, I. H., Titova, T. Ye., Sedykh, K. V., Giacomuzzi, S., Ertl, M., \& Rabe, M. (2020). Psykholohichne blahopoluchchia osobystosti v period pandemii COVID-19 [Psychological well-being of the individual during the COVID-19 pandemic]. Psykholohiia i osobystist [Psychology and personality], 2(18), 55-76. (in Ukrainian)

7. Kharchenko, A. S., \& Honcharova, N. O. (2017). Osoblyvosti psykholohichnoho blahopoluchchia studentiv iz riznym typom spriamovanosti [Features of psychological well-being of students with different types of orientation]. Psykholohiia $i$ osobystist [Psychology and personality], 2(12), 185-193. (in Ukrainian) 